\title{
Species diversity and biogeographical patterns of Laurencia sensu stricto (Rhodophyta) in the Atlantic Ocean
}

\section{Diversidad de especies y patrones biogeográficos de Laurencia sensu stricto (Rhodophyta) en el océano Atlántico}

\author{
Oscar E. Hernández ${ }^{1,2}$, Abel Sentíes², Kurt M. Dreckmann², Valéria Cassano ${ }^{3}$ and Mutue T. Fujii ${ }^{4}$ \\ ${ }^{1}$ Estudiante del Doctorado en Ciencias Biológicas y de la Salud. Universidad Autónoma Metropolitana, Unidad Iztapalapa. A.P. 55-535, CDMX, 09340, México \\ ${ }^{2}$ Departamento de Hidrobiología, Universidad Autónoma Metropolitana-Iztapalapa, A.P. 55-535, CDMX, 09340, México \\ ${ }^{3}$ Departamento de Botânica, Universidade de São Paulo, Rua do Matão 277, São Paulo 05508-090, Brazil \\ ${ }^{4}$ Núcleo de Pesquisa em Ficologia, Instituto de Botânica, Av. Miguel Estéfano, 3687-04301-902 São Paulo, Brazil \\ e-mail: oehc90@gmail.com
}

Recibido: 31 de mayo de 2017.

Aceptado: 30 de octubre de 2017.

Hernández 0. E., A. Sentíes, K. M. Dreckmann, V. Cassano and M. T. Fujii. 2017. Species diversity and biogeographical patterns of Laurencia sensu stricto (Rhodophyta) in the Atlantic Ocean. Hidrobiológica 27 (3): 301-314. D0l: 10.24275/uam/izt/dcbs/hidro/2017v27n3/Hernadez

\begin{abstract}
Background. Recent morphological and phylogenetic studies of Laurencia in the Atlantic Ocean have modified our current knowledge of the group. Approximately $23 \%$ of the worldwide generic diversity has been recorded in this region. Goals. Update the checklist of the Laurencia species in the Atlantic and describe the distribution patterns within the genus. Methods. We obtained records of Laurencia species in the Atlantic from a review of the literature and distributional data were used to define areas of endemism through a PAE (Parsimony of Areas of Endemism) analysis. Results. We propose an updated checklist of the 30 currently recognized species of Laurencia in the Atlantic Ocean; this checklist also includes taxonomic synonyms, nomenclatural remarks, and a detailed distribution for each species. The distributional range for the genus in the Atlantic extends from Bermuda and Northern Europe in the North Atlantic to Brazil and South Africa in the South Atlantic. We were able to define four areas of endemism: Brazil with four endemic species, the Gulf of Guinea with four endemic species, the northeastern Atlantic with three endemic species, and South Africa with four endemic species; also documented was one secondary area (Macaronesian Islands) with the endemic species $L$. viridis. Moreover, 17 of the 30 species of the Atlantic are also distributed in the Indo-Pacific, of which five are amphi-Atlantic species. Conclusions. The patterns found are related to geological events that occurred in the past, a fact that allows us to formulate a vicariance hypothesis about these species biogeographic history. Therefore, future work that will document new species and the clarification of taxonomic problems will allow researchers to continue enriching this hypothesis.
\end{abstract}

Key words: Area of endemism, biogeography, PAE analysis, red algae.

\section{RESUMEN}

Antecedentes. Los recientes estudios morfológicos y filogenéticos de Laurencia para el océano Atlántico han modificado el conocimiento actual sobre la diversidad del grupo, registrándose para esta región, aproximadamente el $23 \%$ de la diversidad del género a nivel mundial. Objetivos. Actualizar el listado de especies de Laurencia presentes en el Océano Atlántico y definir sus patrones de distribución. Métodos. Se obtuvieron los registros de las especies del género a partir de una revisión bibliográfica, utilizando los datos de distribución para la definición de patrones biogeográficos mediante un análisis de PAE. Resultados. Se propone un listado actualizado que contiene 30 especies de Laurencia reconocidas taxonómicamente para el Océano Atlántico; además se incluyen sinónimos, notas nomenclaturales y la distribución a detalle de cada una de las especies. El intervalo de distribución del género se extiende desde Bermuda y el norte de Europa para el Atlántico Norte, hasta Brasil y Sudáfrica en el Atlántico Sur. Se definieron cuatro áreas de endemismo: Brasil con cuatro especies endémicas, Golfo de Guinea con cuatro especies restringidas, Noreste del Atlántico con tres especies endémicas y Sudáfrica con cuatro especies endémicas; además de un área secundaria (Islas de la Macaronesia) con $L$. viridis como especie endémica. Por otro lado, 17 de las 30 especies registradas para el Atlántico se distribuyen también en el Indo-Pacífico, de las cuales cinco son especies anfi-Atlánticas. Conclusiones. Los patrones encontrados han sido relacionados con eventos geológicos que han ocurrido en el pasado, permitiendo ofrecer una hipótesis de vicarianza sobre su historia biogeográfica. Por lo tanto, trabajos futuros sobre el reconocimiento de nuevas especies y el esclarecimiento de problemas taxonómicos permitirá continuar enriqueciendo dicha hipótesis.

Palabras clave: Áreas de endemismo, biogeografía, Análisis de PAE, algas rojas. 


\section{INTRODUCTION}

There is a need for an updated checklist of Laurencia (Rhodophyta, Ceramiales) in the Atlantic 0cean that accounts for recent morphological and phylogenetic studies that have modified our current knowledge of the group. For instance, the "Laurencia complex" has replaced the former concept of Laurencia sensu lato. The genus Laurencia sensu stricto (s.s.) (Garbary \& Harper, 1998; Nam, 2006; Gil-Rodríguez et al., 2012), and the following seven genera belonging to the complex (mentioned above):Osmundea Stackhouse, Chondrophycus (Tokida et Saito) Garbary et J. T. Harper, Palisada K. W. Nam, Yuzurua (K.W. Nam) Martin-Lescanne, Laurenciella Cassano, Gil-Rodríguez, Sentíes, DíazLarrea, M. C. Oliveira et M. T. Fujii, Coronaphycus Metti and Ohelopapa F. Rousseau, Martin-Lescanne, Payri et L. Le Gall. These genera differ in the number of pericentral cells cut off by the vegetative axial segments, the origin of spermatangial branches, and the origin of tetrasporangia from determined cells (Saito, 1967; Nam et al., 1994; Garbary \& Harper, 1998; Nam, 1999, 2006, 2007). Molecular phylogenetic data also support distinction among them (Martin-Lescanne et al., 2010; Cassano et al., 2012a; Metti et al., 2015; Rousseau et al., 2017).

Laurencia comprises 130 taxonomically recognized species worldwide (Guiry \& Guiry, 2017). In particular, 18 species of the genus have been recorded for the Western Atlantic (from North Carolina to Brazil) and 21 for the Eastern Atlantic (Europe and Africa). These represent $23 \%$ of the species richness worldwide. Phylogenetic studies of some Laurencia species in the Atlantic have shown the artificiality of the wide ranges of distribution of some species, such as $L$. microcladia and $L$. obtusa (Cassano et al., 2012a) that have been eliminated from the Brazilian flora.
The area of endemism is defined as the sympatric congruence between two or more endemic species, based on the fact that these species share a common spatial history (Platnick, 1991; Morrone, 2007). Other areas that can be documented are the secondary areas, which have only one endemic species or the so-called relic species that are important because these areas may be later isolations where species radiation has not yet occurred (Ippi \& Flores, 2001; Vargas et al., 2008). The PAE (Parsimony Areas of Endemism) analysis is a method that allows us to identify areas of endemism from area cladograms. In a manner similar to phylogenetic systematics, at least two synapomorphic characters (restricted species) will define areas of endemism (Morrone, 2013).

One important outcome of this taxonomic updating is to provide a better understanding of the biogeographical patterns. With the present updated checklist, we will discuss endemism and the widespread geographic distribution of Laurencia species in the Atlantic.

\section{MATERIALS AND METHODS}

Records for Laurencia for the Atlantic Ocean were obtained from primary sources (these sources are indicated for each species in Results section). We complemented information with the online database Algae Base (Guiry \& Guiry, 2017). Parsimony Analysis of Endemicity (PAE; Rosen, 1988) was used in a biogeographical analysis. For this analysis, an $r \times c$ binary matrix (presence and absence) was constructed, where $r$ (rows) displays the 17 Atlantic ecoregions proposed by Spalding et al. (2007) (Fig. 1) and $c$ (columns) contains 24 of the 30 species recorded for the Atlantic Ocean. Because they could be found practically all over

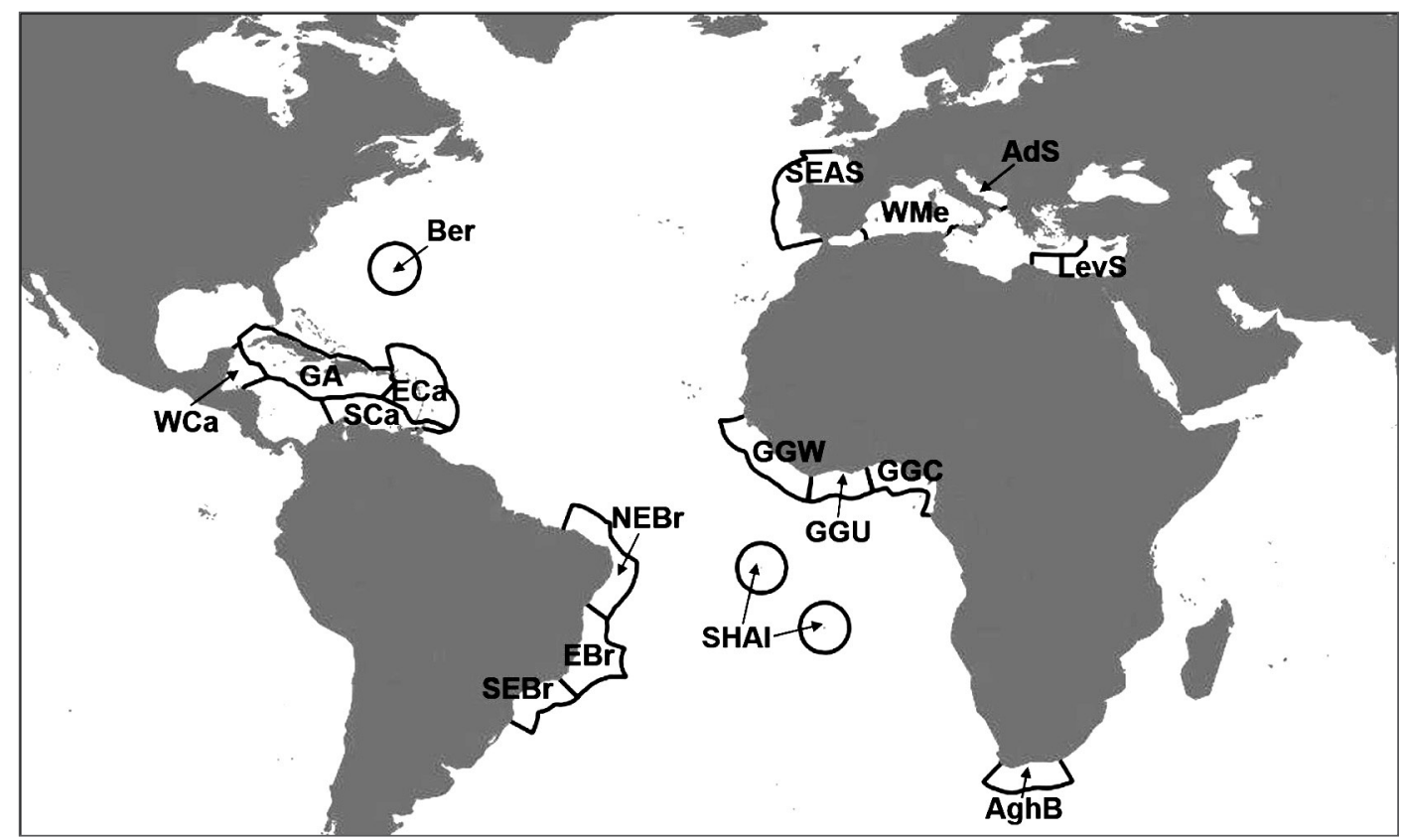

Figure 1. Marine ecoregions used in the PAE analysis, modified from Spalding et al., (2007): Adriatic Sea (AdS), Aghulas Bank (AghB), Bermuda (Ber), Eastern Brazil (EBr), Eastern Caribbean (Eca), Greater Antilles (GA), Gulf of Guinea Central (GGC), Gulf of Guinea Upwelling (GGU), Gulf of Guinea Western (GGW), Levantine Sea (LevS), Northeastern Brazil (NEBr), Southern Caribbean (Sca), South European Atlantic Shelf (SEAS), Southeastern Brazil (SEBr), St. Helena and Ascension Islands (SHAI), Western Caribbean (WCa), and Western Mediterranean (WMe). 
the Atlantic, we did not include L. brongniartii J. Agardh, L. caduciramulosa Masuda et S. Kawaguchi, L. dendroidea J. Agardh, L. intricata J. V. Lamouroux, L. microcladia Kützing, and L. obtusa (Hudson) J.V. Lamouroux. In addition, the Macaronesian Islands were excluded from the analysis because they are considered to be a transition zone with species from other areas of Atlantic (see Haroun \& Prud'homme van Reine, 1993; Tuya \& Haroun, 2009), and may affect our distributional patterns (Medina, 2007). Parsimony analysis was done through a heuristic search using TBR+TBR routines with the NONA program, using the WinClada software (Nixon, 1999). A strict consensus tree was built from the most parsimonious trees.

Six "species inquirenda" (L. alsidiidormis Zanardini ex Fraudenfeld, L. alsidioides P. L. Crouan et H.M. Crouan, L. botryocephala Kützing, $L$. canariensis Montagne ex Kützing, L. moriformis Kützing and L. trifaria Kützing) did not provide information about their geographical distribution and were recorded only once by their respective authors. Null or limited herbarium material prevented us from being totally certain about these taxa. Categories of areas (patterns) were defined: Those containing an endemic species (Secondary Area); those with congruence in geographical distribution of two or more endemic species (Area of Endemism), that is, clades defined by two or more synapomorphies; and widespread species (amphi-Atlantic Areas). In addition, we defined areas containing two or more endemic species without total congruence in the geographic distribution of these, known as areas of Partial Congruence.

\section{RESULTS}

Checklist of Laurencia species

\section{Laurencia aldingensis Saito et Womersley}

Type locality: Aldinga Reef, South Australia.

Distribution: Tropical Southwestern Atlantic: BRAZlL: Espírito Santo (Carvalho et al., 2006; Fujii et al., 2011) and Rio de Janeiro (Fujiiet al., 2011).

\section{Laurencia brachyclados Pilger}

Type locality: Annobon Island, Equatorial Guinea, West Africa.

Distribution: Gulf of Guinea: Equatorial GuINEA: Annobon Island (John et al., 2004).

St. Helena and Ascension Islands: Ascension IsLand (John et al., 2004).

\section{Laurencia brongniartii J.Agardh}

Type locality: Martinique, West Indies.

Remarks: Dizerbo \& Herpe (2007) and Stokes et al. (2004) considered this an introduced species in southeast France and Ireland, respectively.

Distribution: Gulf of Guinea:GHANA (John et al., 2004).

Luisitanian: CANARY ISLANDS: El Hierro and Lanzarote (uncertain record) (Gil-Rodríguez et al., 2012). France: Brest (Dizerbo \& Herpe, 2007).
Tropical Northwestern Atlantic: Costa RicA: Punta Coclas (Fernández \& Alvarado, 2004). CuBA: Havana (Suárez, 2005). Martinique (Womersley, 2003). Mexico: Quintana Roo (Sentíes \& Fujii, 2002).

Northern European Seas: IRELAND (Stokes et al., 2004).

\section{Laurencia caduciramulosa Masuda et Kawaguchi}

Type locality: Hon Tre Island, Tien Hai Islands, Hatien, KienGiang Province, Vietnam.

Distribution: Lusitanian: CanaRY IsLandS: Tenerife (Gil-Rodríguez et al., 2012).

Mediterranean Sea: FrancE: Mediterranean coast (Klein \& Verlaque, 2005). GREECE: Zakynthos Island (Tsikira \& Haritonidis, 2005). ITALY: Linosa Island (Furnari et al., 2001; Serio et al., 2006).

St. Helena and Ascension Islands: Ascension IsLAND (Tsiamis et al., 2014a).

Tropical Northwestern Atlantic: CuBA: Havana (Sentíes et al., 2010) and Rincón del Guanabo (Suárez et al., 2015). USA: Florida (Collado-Vides et al., 2014).

Tropical Southwestern Atlantic: BrAzlL: Bahia (Torrano-Silva \& Oliveira, 2013) and Rio de Janeiro (Cassano et al., 2006).

\section{Laurencia caraibica P.C. Silva}

Type Locality: Abraham Bay, Mariguana (Mayaguana), Bahamas.

Distribution: Tropical Northwestern Atlantic: BaHAmAs: Abraham Bay (Schneider et al., 2010). Belzz: Carry Bow Cay (Norris \& Bucher, 1982) and Pelican Cays (Littler \& Littler, 1997). CuBA: Bucunayagua, Guanahacabibes and Havana (Suarez, 2005). Jamaica (Taylor, 1960). Lesser Antilles (Taylor, 1969). México: Campeche, Quintana Roo, Tamaulipas, and Veracruz (Ortega et al., 2001; Sentíes \& Fujii, 2002). Venezuela (Ganesan, 1990).

Tropical Southwestern Atlantic: BrAzlL: Rio Grande do Norte (Villaça et al., 2010) and Bahia (Creed et al., 2010).

Warm Temperate Northwest Atlantic: BermudA: Bermuda Island, Gibbet Island, and Somerset Island (Schneider et al., 2010).

\section{Laurencia catarinensis Cordeiro-Marino et M.T. Fujii}

Type locality: Mole Beach, Santa Catarina Island, Brazil.

Distribution: Lusitanian: Canary IsLands: El Hierro, Fuerteventura, Gran Canaria, La Gomera, La Palma, Lanzarote and Tenerife (Machín-Sánchez et al., 2012).

WarmTemperate Southwestern Atlantic: BrazlL: Santa Catarina (Fujii \& Sentíes, 2005; Machín-Sánchez et al., 2012) and São Paulo (Fujii et al., 2006).

Tropical Southwestern Atlantic: Brazll: Rio Grande do Norte (Fujii \& Sentíes, 2005; Machín-Sánchez et al., 2012), Espírito Santo (Machín-Sánchez et al., 2012) and Rio de Janeiro (Fujii \& Sentíes, 2005). 


\section{Laurencia chondrioides Børgesen}

Type locality: Saint John Island, U. S. Virgin Islands.

Remarks: Only one record outside the Atlantic (Philippines) by Silva et al., (1987). In the Mediterranean Sea (France and Israel) it is regarded as an invasive species (Klein \& Verlaque 2011; Hoffman et al., 2014).

Distribution: Lusitanian: Canary IsLANDS: Lanzarote (Gil-Rodríguez et al., 2012).

Mediterranean Sea: FrancE: Hyères and Porquerolles Island (Klein \& Verlaque, 2011). GreECE: Zakynthos Island (Tsirika \& Haritonidis, 2005). Israel: Achziv Beach, Achziv Reserve, Haifa-Bat Galim Beach, Rosh Hanika and Shavei Zion (Hoffman et al., 2014). ItaLY: Aeolian Islands, Lachea Island (GómezGarreta et al., 2001), Linosa Island (Serio et al., 2006), Tremiti Islands (Gómez-Garreta et al., 2001) and Tuscany (Rindi et al., 2002). Spain: Balearic Islands and Columbretes Island (Gómez-Garreta et al., 2001).

Tropical Northwestern Atlantic: CuBA: Canarreos Archipelago and Alonzo Cay (Suárez, 2005). Mexico: Quintana Roo (Ortega et al., 2001). VIRGIN IsLANDS: St John (Klein \& Verlaque, 2011).

\section{Laurencia coronopus J. Agardh}

Type locality: "in mare Nigro ad littusTauriae” (Black Sea).

Remarks: Gómez-Garreta et al., (2001) suggested that a revision using recent taxonomic criteria should be made to corroborate if this species actually belongs to Laurencia or whether it belongs to Chondrophycus or Osmundea.

Distribution: Black Sea: Bulgaria: Athopol (Gómez-Garreta et al., 2001; Kamenarska et al., 2006; Kamenarska et al., 2009). Romania LitToral: (Caraus, 2012; Gómez-Garreta et al., 2001).

Mediterranean Sea: France: Herault (Gómez-Garreta et al., 2001).

\section{Laurencia corymbosa J. Agardh}

Type locality: Cape of Good Hope, South Africa.

Distribution: South Africa: Cape of Good Hope (Silva et al., 1996).

\section{Laurencia decumbens Kützing}

Type locality: New Caledonia.

Distribution: Tropical Northwestern Atlantic: BermudA: Bermuda Island (Schneider \& Lane, 2005). Venezuela (Ganesan, 1990).

Tropical Southwestern Atlantic: BrazlL: Atol das Rocas (Villaça et al., 2010).

\section{Laurencia dendroidea J.Agardh}

Type locality: Brazil.

Remarks: According to Cassano et al. (2012b), using molecular and morphological characters, the taxa that have been identified as L. filiformis, L. majuscula, and L. obtusa in Brazil correspond to $L$. dendroidea. Similarly, $L$. majuscula in the Canary Islands corresponds to $L$. dendroidea.

Distribution: Gulf of Guinea: Cameroon, Gabon, and Ghana (John et al., 2004).

Lusitanian: Canary Islands: Fuerteventura, Gran Canaria, La Palma, Lanzarote, and Tenerife (Gil-Rodríguez et al., 2012). Madeira ArChipelago: Madeira (John et al., 2004). Mediterranean Sea: France [uncertain record (Gómez-Garreta et al., 2001)]. GREECE: Zakynthos Island (Tsikira \& Haritonidis, 2005). ITALY: Lecce and Linosa Island (Gómez-Garreta et al., 2001; Serio et al., 2006).

Tropical Northwestern Atlantic: BaRBADos (Taylor, 1960, Wynne et al., 2014). Bermuda (Taylor, 1960). Costa Rica (Taylor, 1960). Jamaica (Taylor, 1960). LesSer Antilles (Taylor, 1960). Netherlands Antilles, Trinidad and Tobago, and Venezuela (Taylor, 1960).

Tropical Southwestern Atlantic: BrazlL: Bahia (Oliveira et al., 2013). Espírito Santo (Oliveira et al., 2013; Fujii et al., 2006) and Rio de Janeiro (Cassano et al., 2012b, Oliveira et al., 2013)

West African Transition Zone: Cape Verde Islands and Salvage IsLandS (John et al., 2004), Gambia (John et al., 2004). SenEGaL: North of Senegal (John et al., 2004).

Warm Temperate Northwest Atlantic: USA: North Carolina (Taylor, 1960).

Warm Temperate Southwestern Atlantic: BrAzll: Santa Catarina (Creed et al., 2010) and São Paulo (Cassano et al., 2012b).

\section{Laurencia epiphylla F. Boisset et J. C. Lino}

Type locality: Alicante: La Granadella, Jávea, the Mediterranean coast of Spain.

Distribution: Mediterranean Sea: SpaIn: Alicante (Gómez-Garreta et al., 2001).

\section{Laurencia flexuosa Kützing}

Type locality: "Ad Caput Bonae Spei”, South Africa.

Distribution: South Africa: CAPE Town (Stegenga et al., 1997).

West African Transition: MauRITANIA [uncertain record (John et al., 2004)].

\section{Laurencia foldatsii N. Rodríguez de Rios}

Type locality: Taguao, Distrito Federal, Venezuela

Distribution: Tropical Northwestern Atlantic: VenezUeLA (Ganesan, 1990).

\section{Laurencia galtsoffii M. Howe}

Type locality: Pearl and Hermes Reef, Hawaiian Archipelago.

Distribution: Gulf of Guinea: GABON, GHana, and LiberiA (John et al., 2004).

West African Transition: Cape Verde Islands (John et al., 2004).

\section{Laurencia griseaviolacea M.J. Wynne}

Type locality: Clovelly, Cape Peninsula, South Africa. 
Distribution: South Africa: CAPE Town (Stegenga et al., 1997, as Laurencia peninsularis $\mathrm{H}$. Stegenga, J. J. Bolton et R. J. Anderson not $L$. peninsularis Taylor).

\section{Laurencia intricata J.V. Lamouroux}

Type locality: Antilles.

Remarks: According to Machín-Sánchez et al. (2012), records of $L$. intricata from the Canary Islands correspond to $L$. catarinensis. Therefore, we believe that a taxonomic study of this species from the rest of Macaronesian Archipelago and Western Africa is needed to verify the identity of $L$. intricata from these areas.

Distribution: Gulf of Guinea: SaO Tomé and PrinciPe, and SierRa LEONE (John et al., 2004).

Mediterranean Sea: GREECE: Messolonghi (Christia et al., 2011) and Zakynthos Island (Tsikira \& Haritonidis, 2005). ITALy. Linosa Island (Furnari et al., 2001; Gómez-Garreta et al., 2001). LıBYA: Cyrenaica (Gómez-Garreta et al., 2001).

Tropical Northwestern Atlantic: Bahamas (Taylor, 1960). BelzE: Carrie Bow Cays (Norris \& Bucher, 1992) and Pelican Cays (Littler \& Littler, 1997). Bermuda: (Taylor, 1960). CAYMAN IsLAND and Costa Rica (Taylor, 1960). Cuba: Canarreos Archipelago, Sabana-Camagüey Archipelago, Nuevitas Bay, Bocas de Alonzo, Coco, Gulf of Batabanó, Guanacahabites, Guardalavaca, Havana, Matanzas, and Villa Clara (Suárez, 2005; Gil-Rodriguez et al., 2010). HISPANIOLA IsLAND and JAMAica (Taylor, 1960). Martinique (Rodriguez-Prieto et al.,1999). Mexico: Campeche (Fujii et al., 2006) and Quintana Roo (Sentíes \& Fujii, 2002, Cassano et al., 2010; Gil-Rodríguez et al., 2010). Panama (Taylor, 1960). Trinidad And Tobago (Duncan \& Lee-Lum, 2006). USA: Florida (Collado-Vides et al., 2011; Fujii et al., 2006). Venezuela: Miranda State (Wynne, 2017). Virgen Islands: St. Croix (Taylor, 1960).

West African Transition: Cape Verde IsLands [uncertain record (John et al., 2004)] and Senegal (John et al., 2004).

Warm Temperate Northwest Atlantic: USA: Texas (Wynne, 2008).

\section{Laurencia laurahuertana Mateo-Cid, Mendoza-González, Sentíes et Díaz-Larrea}

Type locality: Punta Herrero, Quintana Roo. México

Distribution: Caribbean Sea and Gulf of Mexico. Mexico: Quintana Roo (Mateo-Cid et al., 2014).

\section{Laurencia microcladia Kützing}

Type locality: West Indies

Remarks: Records of L. microcladia from Brazil containa misapplied name, which correspond to $L$. dendroidea Cassano et al. (2012a).

Distribution: Lusitania: Azores IsLands: Santa María Island and Pico (Tittley et al., 2009). Canary IsLands: El Hierro, Fuerteventura, Gran Canaria, La Palma, Lanzarote, and Tenerife (Gil-
Rodríguez et al., 2012). MadeIRA ArChIPELAgo: Porto Santo (Neto et al., 2001). SAlvages IsLands (John et al., 2004).

Mediterranean Sea:ALgERIA: Alger (Gómez-Garreta et al., 2001; Gil-Rodríguez et al., 2012). Cyprus: Akamas, GaziMağusa, Girne, Karpasia, Liopetri, and Salamis (Taskin et al., 2013; Tsiamiset al., 2014b). EGYPT: El Dabaa (Gómez-Garreta et al., 2001). France: Corsica (Gómez-Garreta et al., 2001) and Hérault (Verlaque, 2001). GreEcE: Zakynthos Island (Tsikira \& Haritonidis, 2005). ITALY: Linosa Island (Serio et al., 2006), Sicilia (Gómez-Garreta et al., 2001), Tuscan Archipelago (Ridi et al., 2002), Italian Adriatic Sea (Gómez-Garreta et al., 2001), Gulfof Taranto (Gómez-Garreta et al., 2001), Cherad ilslands, and Sardinia (Gómez-Garreta et al., 2001). MALTA: Gozo Island and Malta Island (Comarci et al., 1997). Morocco: Alhucemas, Cabo de Agua, Karia Arkemanne, Muelle Colorado, Punta Negri, Punta de Rostrogordo, and Punta de Sabinilla (GómezGarreta et al., 2001). Spain: Almería (Soto \& Conde, 1989), Balearic Islands (Gómez-Garreta et al., 2001), Catalunya (Gómez-Garreta et al., 2001), and Murcia (Gil-Rodríguez et al., 2012). TuRkey: Akdeniz, Ízmir Bay, Gulf of Gökova, Karadeiz and Mersin (Taskin et al., 2008).

Tropical Northwestern Atlantic: BAHAmAs (Taylor, 1960). BeLIz: Carrie Bow Cays (Norris \& Bucher, 1982) and Pelican Cays (Littler \& Littler, 1997). Bermuda (Taylor, 1960). Caicos IslandS, Cayman Islands, Costa Rica, Jamaica, Lesser Antilles, Netherlands Antilles, and Panama (Taylor, 1960). Cuba: Gulf of Batabanó (Suárez, 2005). Puerto Rico: Arecibo and Santiago Cay (GílRodríguez et al., 2012). TRINIDAD AND ToBago (Duncan \& LumLee, 2006). USA: Florida (Taylor, 1960). Venezuela: Aves Island (Taylor, 1960) and Cumana (Gil-Rodríguez et al., 2012). VIRGIN ISLANDS (Taylor, 1960).

West African Transition: Cape Verde Islands: Ilheu Branco and San Nicolau (John et al., 2004, Gil-Rodríguez et al., 2012). Mauritania (John et al., 2004). Senegal: North of Senegal (John et al., 2004).

\section{Laurencia minuscula Schnetter}

Type locality: Puerto López (Alta Guajira), Guajira Department, Colombia.

Distribution: Tropical Northwestern Atlantic: CoLomBIA: Guajira (Schnetter, 1976). CuBA: Havana (Sentíes et al., 2010).

\section{Laurencia minuta Vandermeulen, Garbary et Guiry}

Type locality: Eilat, Israel.

Distribution: Lusitanian: CANARY IsLANDS: Tenerife ("taxa inquirenda" Haroun et al., 2002; John et al., 2004). SPAIN: Galicia (Bárbara et al., 2005).

Mediterranean Sea: Cyprus: Girne (Taskin et al., 2013). SpaIN: Alicante (Gómez-Garreta et al., 2001). Greece: Zakynthos Island (Tsikira \& Haritonidis, 2005). ITALY: Apulia, Gulf Taranto, Norwesternltaly, and Sicily (Gómez-Garreta et al., 2001), Linosa Island (Serio et al., 2006), and Tuscany (Rindi et al., 2002). MALTA: Malta Island (Gómez-Garreta et al., 2001). 


\section{Laurencia natalensis Kylin}

Type locality: Isipingo Beach, near Durban, South Africa

Distribution: South Africa: Pearly Beach to Agulhas (Stegenga et al., 1997)

\section{Laurencia nidifica J. Agardh}

Type locality: Hawaiian Islands

Distribution: Gulf of Guinea: Ivory COAST,GHANA, AND LIBERIA (John et al., 2004).

Lusitania: MadeIRA ArChIPELAgo: Deserta Grande [uncertain record (Neto et al., 2001)].

St. Helena and Ascension Islands: St. HelenA (John et al., 2004).

West African Transition: Cape Verde IsLands (John et al., 2004).

\section{Laurencia obtusa (Hudson) J. V. Lamouroux}

Type locality: England.

Remarks: Cassano et al. (2012b) confirmed through molecular and morphological characters that records of L. obtusa from Brazil correspond to $L$. dendroidea.

Distribution: Black Sea: BulgaRIA: Ahtopol area (DimitrovaKonaklieva, 1981). RomaniA: Romanian Littoral (Caraus, 2012). TuRkEY: Antalya, Dikili Gelibolu, Gokçeada Island, Izmir Bay, Kirklareli, Korfezi, Mersin, and Zonguldak (Gómez-Garreta et al., 2001; Taskin et al., 2008).

Gulf of Guinea: Cameroon. Equatorial Guinean: Annobon Island. Ghana. Sao Tome and Principe. Sierra Leone (John et al., 2004).

Lusitania: Azores IsLandS: Faial, Pico, Sao Miguel, Terceira, and Santa Maria (Neto, 1994; Tittley \& Neto, 1994). CanarY ISLANDS: El Hierro, Fuerteaventura, Gomera, Gran Canaria, La Palma, Lanzarote Island, and Tenerife (John et al., 2004; GilRodríguez et al., 2012). France: Britanny (Feldmann,1954), Guernsey (Sentíes \& Fujii, 2002), Herault (Ben Maizet al., 1988), and Normandia (Dixon, 1961; Dizerbo \& Herpe, 2007). Madeira Archiplelago: Deserta Grande, Ilhéu de Fora, Madeira, Porto Santo, Selvagem Grande, and Selvagem Pequena (John et al., 2004). Salvage Islands (John et al., 2004). Mauritania (John et al., 2004). Portugal: Beira Litoral, Douro Litoral, and Minho (Araujo et al, 2009). Spaln: Asturias (Cires-Rodríguez \& Cuesta-Moliner, 2010), Basquecoast (Gorostiaga et al., 2004), Cantabria (Martínez-Gil et al., 2007), Galicia (Bárbara et al., 2005; Peña \& Bárbara, 2008), and Vigo (Hamel, 1928).

Mediterranean Sea: AlgeriA: Alger, Annaba, Bab El Oued, Bologhine, El Marsa, Rais Hamidou, Sidi Fredj, Southwest of Cap Bordj El Bahri, and Tipaza (Gómez-Garreta et al., 2001). Croatia: Istria Coast (Munda, 1979). Cyprus: Dip Karpaz, Farmagusta, Gazi Mağusa, Girne, Karpasia, Kumyali, Koruçaim, Kyrenia, Liopetri, Salamis, and Yeşilirmak (Taskin et al., 2013; Tsiamis et al., 2014b). EgyPt: Alexandria (Gómez-Garreta et al., 2001). France: Corsica (Gómez-Garreta et al., 2001; Sales \& Ballesteros, 2010), Hyéres (Augier et al., 1971), Pyrenees Orientales (Gómez-Garreta et al., 2001), and Var (Coppejans, 1972). GREECE: Ionan Islands (Tsikira \& Haritonidis, 2005),
Kleisova (Gómez.Garreta et al., 2001; Christia et al., 2011), Rhodos Island (Diapoulis et al., 1986), and Sporades du Nord (Diannelidis, 1953). IsraEl: Habonim (Gómez-Garreta et al., 2001). Italy: Adriatic Sea (Furnari et al., 1999; Gómez-Garreta et al., 2001), Gulf of Taranto (Cecere et al., 1996), Napoli (Cinelli, 1971; Feoli \& Bressan, 1972), Salerno (Edwards et al., 1975), Sicilia (Serio et al., 2006; Gómez-Garreta et al., 2001), Tuscany (Rindi et al., 2002), and Sardinia (Furnari et al., 2003). LıBYA: Bengazi-Sabri, Cyrenaica, Derna, and Tripoli (Gómez-Garreta et al., 2001). MALtA: Gozo Island (Cormaci et al., 1997). Morocco: Cabo de Agua, Cabo Quilates, Cal Iris, Cala Bonita, Cala Charranes, Cala Viñas, Cazaza, Chafarinas Islands, Karia Arkemanne, Mar Chica, Playa del Quemado, Punta Negri, Punta de Rostrogordo, and Sammar (GómezGarreta et al., 2001). Spaln: Andalusia (Conde et al., 1996; Conde \& Flores-Maya, 2000), Balearic Islands (Gómez-Garreta et al., 2001), Catalunya (Ballesteros, 1981; RodríguezPrieto \& Polo-Albertí, 1988, 1998), Murcia (Pérez-Ruzafa \& Honrubia, 1984; Pérez-Ruzafa, 1990), and Valencia (Barcelo \& Seoane, 1982). Tunisia: Bahiret, Bechateur, Bizerte, Cap Blanc, Cap Farina, Cap Serrat, Cathage, Djerba, El Bibane, Gabès, Gammarth, Ghar El Khebir, Gulf of Gabès, Iles Cani, Kelibia, Kerkennah, Korba, Korbous, La Goulette, La Marsa, Mer de Bou Grara, Monastir, Le Galiton, Raf Raf, Raouad, Ras el Fartass, Salambô, Sidi Bou Said, Sfax, Sídi Raïs, Tabarka, Zarzis, and Zembra (Gómez-Garreta et al., 2001).

Northern European Seas: England: Sussex and Devon (Lipkin \& Silva, 2002). IRELAND: Antrim (Morton, 1994), Clare (De Valéra et al., 1979), Derry (Morton, 1994), Donegal (Morton, 2003), Down (Morton, 1994), Cork, Dublin, Galway, Kerry, Leitrim, Mayo, and Wexford (Guiry, 1978). Sweden (Athanasiadis, 1996).

Tropical Northwestern Atlantic: BahamAs: Berry Island (Sentíes \& Fujii, 2002). Barbados (Wynne et al., 2014). Belze: Carrie Bow Cay (Norris \& Bucher, 1982) and Pelican Cays (Littler \& Littler, 1997). Bermuda: St. Georges Island (Sentíes \& Fujii, 2002; Taylor, 1960). Caicos Island, Cayman Islands, and Colombia (Taylor, 1960). CuBA: Havana City (Sentíes \& Fujii, 2002), Camagüey, Juventud Island, and Matanzas, and Villa Clara (Suárez, 2005). Dominican Republic: Santo Domingo (Sentíes \& Fujii, 2002). Guadeloupe: Pointe de la Verdure (Fujii et al., 2006). Jamaica (Taylor, 1960). Martinique: Pointe des Salines and Ste. Anne (Rodríguez-Prieto \& Michanek, 1999). Mexico: Campeche, Quintana Roo, and Tamaulipas (Ortega et al., 2001; Sentíes \& Fujii, 2002), Veracruz and Yucatán (Ortega et al., 2001). Netherlands Antilles: Bonaire and Curaçao (Sentíes \& Fujii, 2002). Panama: Galeta Point (Sentíes \& Fujii, 2002). PuerTo Rico: Guanica and Jaobos (Sentíes \& Fujii, 2002). TRINIDAD and ToBAgo: Tobago (Taylor, 1960; Sentíes \& Fujii, 2002). USA: Florida (Littler et al., 2008). VenezuelA: Aves Island, Cabagua, Margarita Island, and Pelona Island (Taylor, 1960; Sentíes \& Fujii, 2002; Fujii et al., 2006). VIRGIN IsLands (Taylor, 1960).

Warm Temperature Northwestern Atlantic: USA: Texas (Wynne, 2008).

West African Transition: Cape Verde Archiplelago (John et al., 2004). Gambia (John et al., 2004). SenEgal: North Senegal (John et al., 2004). 


\section{Laurencia oliveirana Yoneshigue}

Type locality: Ponta da Cabeça, Cabo Frio, Rio de Janeiro State, Brazil.

Distribution: Tropical Southwestern Atlantic: BrazlL: Rio de Janeiro (Fujii et al., 2012) and Bahia (Fujii \& Sentíes, 2005).

Warm Temperate Southwestern Atlantic: BrazlL: Rio Grande do Sul and São Paulo (Fujii \& Sentíes, 2005).

\section{Laurencia pyramidalis Bory ex Kützing}

Type locality: Granville, Normandy, France.

Distribution: Lusitania: Azores: Pico, Santa Maria, and Sao Miguel (Machín-Sánchez et al., 2014). Canary IsLands: Fuerteventura, La Gomera, Lanzarote, and Tenerife (Machín-Sánchez et al., 2014). France: Finistère (Bouxin \& Dizerbo, 1971) and Normandy (Machín-Sánchez et al., 2014). MadeIRA ARCHIPELAGo: Ponta de São Jorge-Casi, Porto Moniz-Piscinas, and Seixal-Praia da Laje (Machín-Sánchez et al., 2014). PortugaL: Minho (Araujo et al., 2009). Span: Asturias (Cires-Rodríguez \& Cuesta-Moliner, 2010; Díaz et al., 2008), BasqueCoast (Gorostiaga et al., 2004), Cantabria (Martínez-Gil et al., 2007), Galicia (Bárbara et al., 2005) and Sisargas Island (Veiga et al., 1998).

Mediterranean Sea: Cyprus: Dip Karpaz and Gazi Mağusa (Taskin et al.,2013). ItALY: Adriatic Sea (Furnari et al., 1999) and Sardinia Island (Serio et al., 2004). Spaln: Andalusia (Conde et al., 1996), Catalunya (Ballesteros, 1981), and Murcia (Pérez-Ruzafa \& Honrubia, 1984).

Nothern European Seas: Great Britain and Ireland (Hardy \& Guiry, 2003).

\section{Laurencia tenera C. K. Tseng}

Type locality: Shek-0, Hong Kong.

Distribution: Gulf of Guinea: IvoRy COAST, GHANA, LiBERIA, SIERRA LEone, and Togo (John et al., 2004).

West African Transition: Cape Verde Islands, Gambia, Mauritania, and SenEgal (John et al., 2004).

St Helena and Ascension Islands: St. HelenA (John et al., 2004).

\section{Laurencia translucida M. T. Fujii et Cordeiro-Marino}

Type locality: Padres beach, Aracruz, Espírito Santo State, Brazil.

Distribution: Warm Temperate Southwesern Atlantic: BrazlL: São Paulo (Creed et al., 2010).

Tropical Southwestern Atlantic: Brazll: Bahia, Ceará, and Pernambuco Espírito Santo (Fujii et al., 2006), Rio de Janeiro (Creed et al., 2010).

\section{Laurencia venusta Yamada}

Type locality: Koshiki-jima, Kagoshima Prefecture and Gotoretto, Nagasaki Prefecture, Japan.
Distribution: Tropical Northwestern Atlantic: Méxlco: Quintana Roo (Sentíes \& Fujii, 2002).

Tropical Southwestern Atlantic: BrazlL: Espírito Santo (Fujii \& Sentíes, 2005).

\section{Laurencia viridis Gil-Rodríguez et Haroun}

Type locality: Canary Isands: Tenerife: Punta Hidalgo-Baja Negra.

Distribution: West African Transition: Cape Verde ISLANDS (John et al., 2004).

Macaronesian Archipelago. Azores: Santa María (MachínSánchez et al., 2014). Canary IsLands: El Hierro, Fuerteventura, Gran Canaria, La Gomera, La Palma, Lanzarote, and Tenerife (John et al., 2004; Gil-Rodríguez et al., 2012; Machín-Sánchez et al., 2014). Madeira Archipelago: Ilhéu de Fora, Ponta de Sao Jorge, Porto Santo, and Salvagem Pequena (John et al., 2004; Machín-Sánchez et al., 2014).

\section{Species inquirenda}

\section{Laurencia alsidiiformis Zanardini ex Fraudenfeld}

Type locality: Spalato, Dalmatian coast.

\section{Laurencia alsidioides P. L. Crouan et H.M. Crouan}

Type locality: I. Guadeloupe, Caribbean Sea.

\section{Laurencia botryocephala Kützing}

Type locality:“Ad Caput Bonae Spei” Cape of Good Hope.

\section{Laurencia canariensis Montagne ex Kützing}

Remarks: Gil Rodríguez et al. (2012) suggested that it should be considered an uncertain species. According to John et al. (1994), L. canariensis and L. caespitosa are synonyms of Osmundea hybrida (De Candolle) K. W. Nam.

Type locality: Canary Islands.

\section{Laurencia moriformis Kützing}

Type locality: Cape of Good Hope.

\section{Laurencia trifaria Kützing}

Type locality: Cape of Good Hope.

PAE Analysis. The area cladogram obtained had the following parameters: Length $=28$, Consistency Index $=0.85$ and Retention Index $=0.88$. The strict consensus tree of the 3 equally parsimonious trees is presented (Fig. 2). Cladogram topology suggests four areas of endemism: South Africa (AghB) with four restricted species, Brazil (EB, NEB, and SEB) with four restricted species, Northeastern Atlantic (WMe, SEAS, LevS, and AdS) with three restricted species, and Gulf of Guinea (SHAI, GGU, CV, GGW, and GGC) with four restricted species (Fig. 3). Some of these species, however, are also distributed in the Indo-Pacific (see Table 1). In addition, we have defined three categories of areas: partial congruence (areas with partial congruence between the areas of distribution) composed by GA, ECa, WCa, and SCa (Fig. 2), secondary areas (area with an endemic species, Ippi \& Flores, 2001) and widespread species (Table 1). 


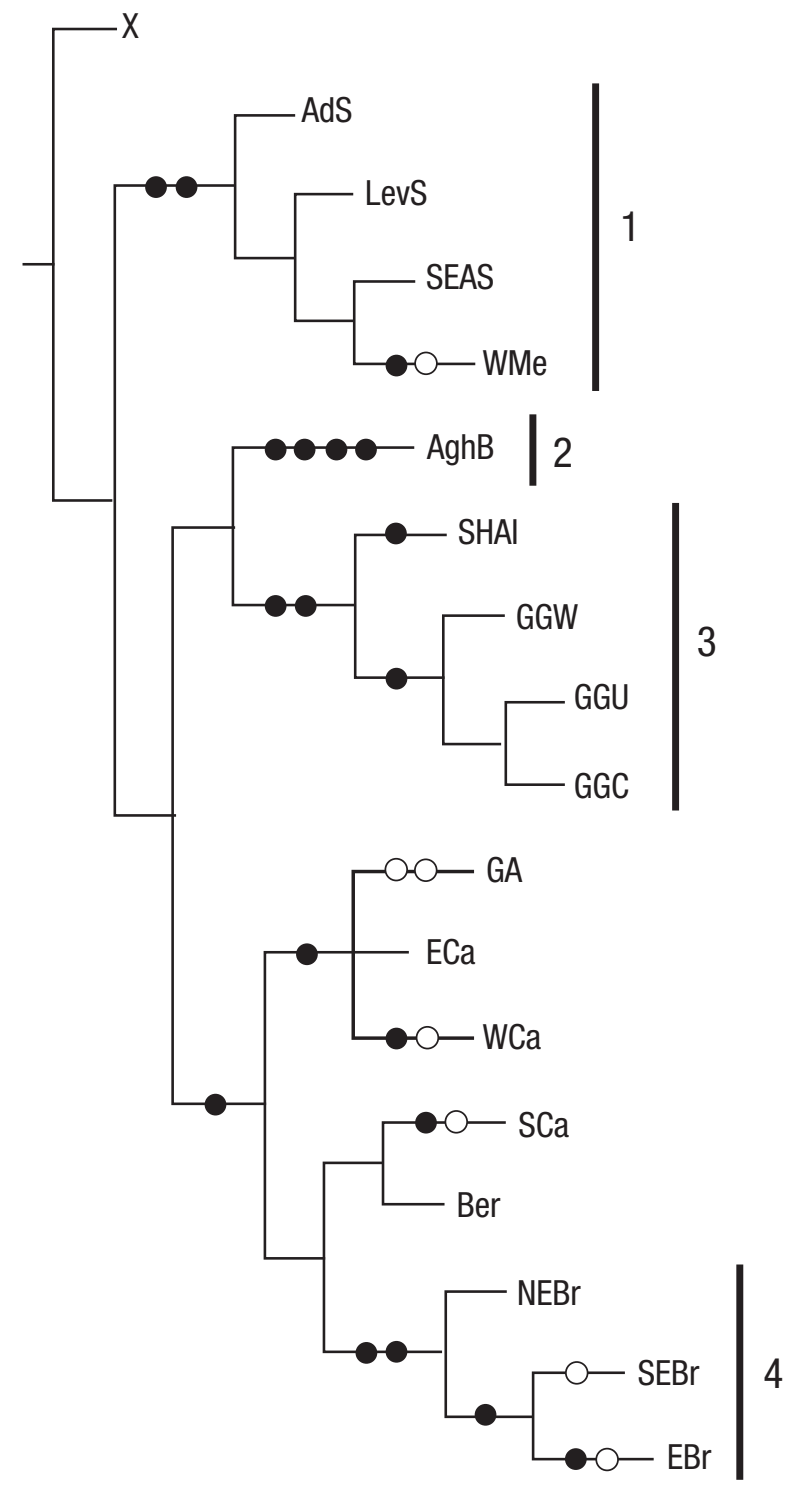

Figure 2. Areas of endemism defined in the PAE analysis. 1) Northwestern Atlantic, 2) South Africa, 3) Gulf of Guinea, and 4) Brazil. The black dots represent restricted species or synapomorphies and the white dots represent homoplasies.

\section{DISCUSSION}

The nomenclature from genus to species, valid names, and taxonomic synonyms of Laurencia are a fundamental part of the checklist here proposed and a topic of continuing discussion among taxonomists. Checklists allow for the documentation of species distributions, the biodiversity within certain areas, and offer the possibility of using this information to carry out a biogeographical analysis; thus, considering the taxonomic remarks, uncertain records, reports of invasion, and introduction of species allows us to obtain biogeographical natural patterns or approximate reality. Taxonomic validity of the records and the recognition of the distribution limits of the species area are essential requirements in biogeographic works (Morrone, 2013). In turn, areas of endemism and secondary areas can be defined, and widespread species identified.

On endemism. Areas of endemism (non-endemic species) are defined as the sympatric distribution congruence of two or more taxa belonging to a given category (e.g., order, family, genus or species) (Morrone, 2013). However, when we take Laurencia, the Caribbean Sea is defined by partial congruence in the distribution of two or more species (group GA, ECa, WCa, and SCa; see Fig. 2). Endemic species inhabit this region, such as $L$. laurahuertana in the western Caribbean, $L$. foldatsii in the southern Caribbean, L. chondrioides, and L. minuscula in the Caribbean Sea in general, but their distributional congruence is not total, and the PAE analysis does not define this area for two or more synapormorphies. Furthermore, the Caribbean Sea is the Atlantic biotic area with the highest species richness of Laurencia (13 spp). This biogeographic pattern is also shared by the distributional diversity of several unrelated taxa, such as coastal fishes, mangroves, coral reefs, and seagrasses in the Atlantic Ocean (Tittensor et al., 2010).

According to Tapia-Silva et al. (2015), a mathematical analysis of the geographic distribution of the macroalgal species richness can reveal high diversity spots that, in the case of macroalgae, coincide well with the major distribution of the great marine environments in the area (mangroves, coral reefs and seagrasses): the Mexican Caribbean barrier reef, the Veracruz reef system, and the Alacran reef system at Puerto Progreso, Yucatan (Vilchis et al., in press). Studies have shown higher macroalgal diversity in the Indo-Pacific area than in the Atlantic (Kerswell, 2006), and when comparing worldwide Laurencia data (Tapia et al., 2015) this pattern is confirmed. Areas of endemism in the south Atlantic were also found in Brazil, Gulf of Guinea, and South Africa, which are also reported to contain endemic species (Brown \& Lomolino, 1998); furthermore, it was found that the Gondwana breakup is the geological process that explains this endemism.

Other areas such as the Northwestern Atlantic, Europe, and the Caribbean Sea share Laurencia species with other regions (i.e., the IndoPacific), and the influence of vicariance events such as the closing of Isthmus of Panama and the final closure of the Tethys seaway in the Eastern Atlantic (Cowman \& Bellwood, 2013) has not been studied.

Secondary areas. These areas are defined by the presence of one endemic species. When this happens, for example, in the Macaronesian Archipelago with $L$. viridis, the area is inhabited mostly by species that are also distributed in other places (9 spp.), and the number of endemic species is smaller compared to the defined areas of endemism. In the Macaronesian Archipelago, the phycofloristic composition reveals elements in common with the littoral of continental Europe and the North of Africa (Haroun and Prud'Homme van Reine, 1993; Tuya \& Haroun, 2009). This is because the geological origin of the Macaronesian islands dates to the early Miocene (20 my) (Brown \& Lomolino, 1998), allowing the colonization of species from other areas. Thus, this region is a special biotic area that could be researched using an island-biogeography approach.

Widespread species. The genus Laurencia in the Atlantic Ocean extends from the coast of Ireland to South Africa, including the Mediterranean Sea and Black Sea; in the western Atlantic, the genus extends from North Carolina, USA, to southern Brazil. Seventeen of these species are also distributed in the Indo-Pacific, of which five are widely distributed in the Atlantic 0cean. 
Table 1. Categories of areas defined for Laurencia in the Atlantic Ocean.

\begin{tabular}{|c|c|c|}
\hline Categories & Defined Area & Species \\
\hline \multirow[t]{4}{*}{ Areas of Endemism } & Atlantic Northeastern Ocean & L. coronopus, L. minuta*, L. pyramidalis ${ }^{+}$. \\
\hline & Brazil & L. aldingensis*, L. catarinensis ${ }^{+}$, L. oliveirana, L. translucida. \\
\hline & Gulf of Guinea & L. brachyclados*, L. galtsoffii*, L. nidifica*, L. tenera*. \\
\hline & South Africa & L. corymbosa* , L. flexuosa, L. griseaviolacea, L. natalensis ${ }^{\star}$ \\
\hline Partial Congruence & Caribbean Sea & L. chondrioides, L. epiphylla, L. foldatsii, L. laurahuertana, L. minuscula* \\
\hline \multirow[t]{2}{*}{ Secondary Areas } & Macaronesian Islands & L. viridis \\
\hline & American Atlantic & L. caraibica* ${ }^{*}$ L. decumbens ${ }^{*}, L$ venusta* \\
\hline \multirow[t]{2}{*}{ Amphi-Atlantic } & Northern Atlantic & L. microcladia ${ }^{*+}$ \\
\hline & Widespread in the Atlantic Ocean & L. brongniartii ${ }^{*}$, L. caduciramulosa* ${ }^{*+}$, L. dendroidea ${ }^{*+}$, L. intricata $^{*}$, L. obtusa ${ }^{*+}$ \\
\hline
\end{tabular}

*Species also distributed in the Indo-Pacific. ${ }^{+}$Species also distributed in the Macaronesian Archipelago.

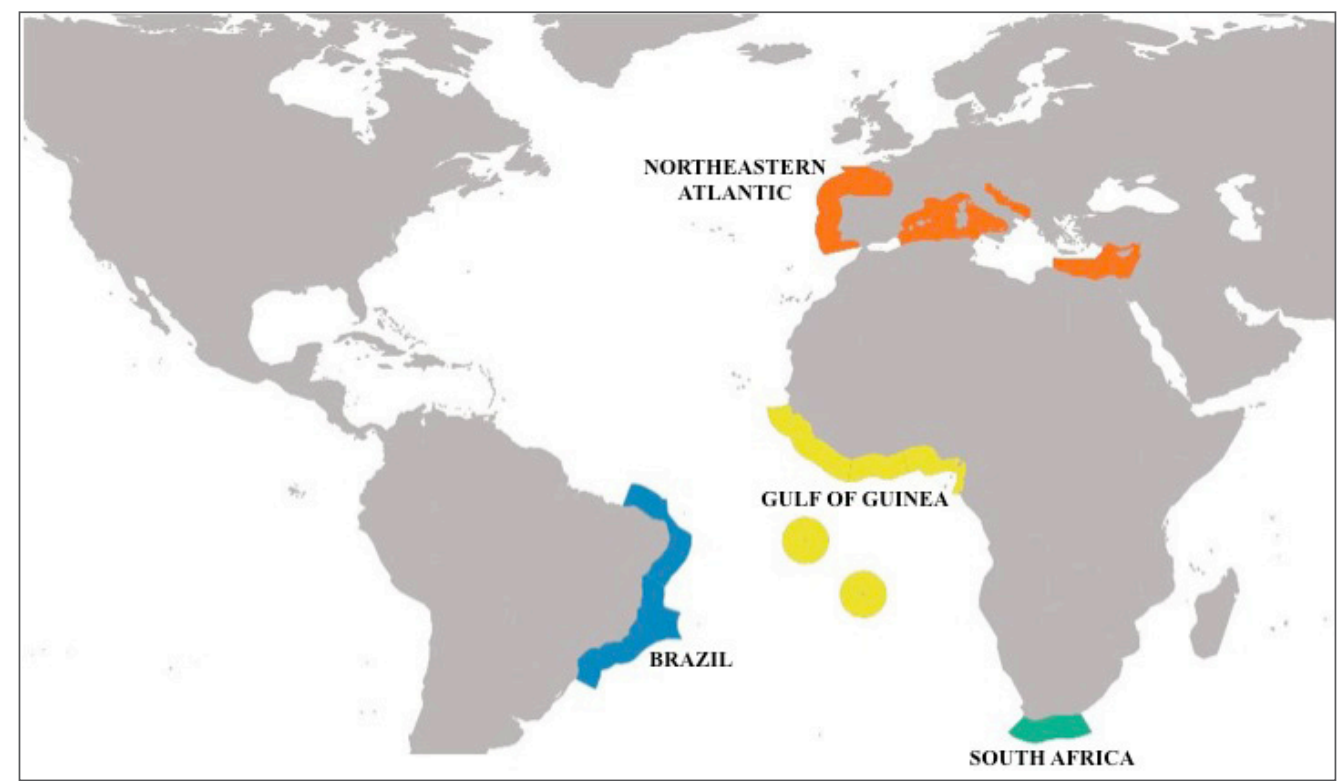

Figure 3. Map of the areas of endemism of Laurencia in the Atlantic Ocean.

Recent phylogenetic studies have been useful in detecting misidentifications in the Atlantic, especially in records from Macaronesia, Brazil, and the Mexican Caribbean, although only nine widespread species of Laurencia in the Atlantic have a molecular characterization in these places. The use of the molecular-phylogenetic approach on these species in the Atlantic 0cean should allow us to identify new lineages over a wide distribution range, as has happened with other groups of red algae (Skage et al., 2005; Nuñez-Resendiz et al., 2015), and achieve a much better understanding of the historical biogeography of Laurencia in the Atlantic Ocean.

According to Miranda and Marques (2011), the two principal obstacles in the biogeographical works are (1) the reliability of species identifications and the consequent uncertainty of the presence of species in a given area, and (2) the difficulty in producing reliable cladograms from phylogenies.
In conclusion, it has been possible to establish a biogeographic pattern in Laurencia from the definition of areas of endemism and partial and secondary areas. This pattern has been linked to geological events that occurred in the past. Therefore, the recognition of new species from systematics studies and the clarification of taxonomic problems will allow researchers to continue developing a biogeographic hypothesis for the genus in the Atlantic Ocean.

\section{ACKNOWLEDGEMENTS}

The first author wishes to thank the Universidad Autónoma Metropolitana-Iztapalapa and CONACyT. We also thank the following projects: UAMI, Consejo de la Div. C.B.S., (Sesión 15.14-131014) and Secretaría de Educación Pública-PROMEP (UAMI-CA-117), the São Paulo Research Foundation (FAPESP, 2014/00012-1), and CONACyT. Finally, we thank Michael Wynne for his comments on the manuscript. 


\section{REFERENCES}

Araujo, R., I. Bárbara, M. Tibaldo, E. Berecibar, P. Diaz-Tapia, R. Pereira, R. SAntos \& I. Sousa-Pinto. 2009. Checklist of benthic marine algae and cyanobacteria of Northern Portugal. Botanica Marina 52 (1): 24-46. DOI: 10.1515/BOT.2009.026

AthANASIADIS, A. 1996. Taxonomisk litteratur och biogeografi av Skandinaviska rödalger och brunalger. Göteborg. Algologia, Göteborg. 280 p.

Augier, H., C.F. Boudouresque \& J. Laborel. 1971. Végétation marine de l'Île de Port Cros (Parc National). VII. — Les peuplements sciaphiles profonds sur substrat dur. Bulletin du Museum d'Histoire Naturelle de Marseille 31: 153-183.

Ballesteros, E. 1981. Contribució al coneixement algològic de la Mediterrània Espanyola: algues bentòniques i litorales de Tossa de Mar (Girona). Bulletí de la Institució Catalana d'Història Natural 46 (Sec. Bot. 4): 55-73. Avaliable online at: http://www.raco.cat/index.php/ ButlletilCHN/article/view/235801/318064.

Bárbara, I., J. Cremades, S. Calvo, M.C. López-Rodríguez \& J. Dosil. 2005. Checklist of the benthic marine and brackish Galician algae (NW Spain). Anales del Jardín Botánico de Madrid 62 (1): 69-100.

Barcelo, M. C. \& J. A. Seoane. 1982. Aportació al coneixement de las algues marines de les costes del Pais Valencià. Collectanea Botanica 13 (2): 767-775.

Ben Maiz, N., C. F. Boudouresque, M. Laurent \& R. Riouall. 1988. Inventaire bibliographique des macrophytes (Algues, Phanérogames) signales dans l'Etang de Thau (Herault, France). Naturalia Monspeliensia. Série Botanique 52: 71-84.

Bouxin, H. \& A. H. Dizerbo. 1971. Les algues de l'Archipel des Glenan (Finistere). Botanica Rhedonica. Serie A (10): 199-226.

Brown J. H. \& M. V. Lomolino. 1998. Biogeography, 2nd edition. Sinauer Associates, Massachusetts. 691 p.

Caraus, I. 2012. Algae of Romania: A distributional checklist of actual algae version 2.3, 3rd revision. University of Bacau, Bacau. 809 p.

Carvalho, L. R., M. T. Fujl, N. F. Roque \& J. H. G. Lago. 2006. Aldingenin derivates from the red alga Laurencia aldingensis. Phytochemistry 67 (13): 1331-1335. DOI: 10.1016/j.phytochem.2006.04.020

Cassano, V., M. T. M. de Széchy \& M. T. FuJII. 2006. Laurencia caduciramuIosa (Ceramiales, Rhodophyta) from Ilha Grande Bay, Rio de Janeiro, Brazil: a recent introduction into the Atlantic Ocean? Cryptogamie Algologie 27 (3): 265-277.

Cassano, V., M. C. Gill-Rodríguez, A. Sentíes \& M. T. Fujll. 2008. Laurencia caduciramulosa (Ceramiales, Rhodophyta) from the Canary Islands, Spain: a new record for the eastern Atlantic Ocean. Botanica Marina 51 (2): 156-158. DOI: 10.1515/BOT.2008.021

Cassano, V., M. C. Oliveira, M. C. Gil-Rodríguez, A. Senties, J. Diaz-Larrea \& M. T. FuJll. 2012a. Molecular support for the establishment of the new genus Laurenciella within the Laurencia complex (Ceramiales, Rhodophyta). Botanica Marina 55 (4): 349-357. DOl: 10.1515/bot2012-0133

Cassano, V., Y. Metti, A.J.K. Mlllar, M.C. Gil-Rodriguez, A. Senties, J. DiazLarrea, M.C. Olivelra \& M.T. FuJII. 2012b. Redefining the taxonomic status of Laurencia dendroidea (Ceramiales, Rhodophyta) from Brazil and the Canary Islands. European Journal of Phycology 47 (1): 67-81. DOI: 10.1080/09670262.2011.647334

Cecere, E., M. Comarci, G. Furnari, A. Petrocelli, O. Saracino \& D. Serio. 1996. Benthic algal flora of Cheradi Islands (Gulf of Taranto, Mediterranean Sea). Nova Hedwigia 62 (1): 191-214.

Christia, C., I. Tziortzis, G. Fyttis, L. Kashta \& E. Pastergiadou. 2011. A survey of the benthic aquatic flora in transitional water systems of Greece and Cyprus (Mediterranean Sea). Botanica Marina 54 (2): 169-178. DOI: $10.1515 /$ bot.2011.016

Cinelu, F. 1971. Alghe bentoniche di profundità raccolte alla punta S. Pancrazio nell'Isola di Ischia (Golfo di Napoli). Giornale Botanico Italiano 105: 207-236. D0l: 10.1080/11263507109426526

Cires-Rodriguez, E. \& C. Cuesta-Moliner. 2010. Checklist of benthic algae from the Asturias coast (North of Spain). Boletín Ciencias Naturales RIDEA 51: 135-212.

Collado-Vides, L., V. Mazzeí, T. Thyberg \& D. Lirman. 2011. Spatio-temporal patterns and nutrient status of macroalgae in a heavily managed region of Biscayne Bay, Florida, USA. Botanica Marina 54 (4): 377390. DOI: $10.1515 /$ bot.2011.046

Collado-Vides, L., V. Cassano, J. Díaz-Larrea, A. Duran, A. Da-Silva-Medeiros, A. Senties \& M. Toyota-FuJll. 2014. Spread of the introduced species Laurencia caduciramulosa (Rhodomelaceae, Rhodophyta) to t,he northwest Atlantic: A morphological and molecular analysis. Phytotaxa 183 (2): 93-107. D0I: 10.11646/phytotaxa.183.2.2

Cormacl, M., E. Lanfranco, J.A. Borg, S. Buttigieg, G. Furnari, S.A. Micallef, C. Mifsud, F. Pizzuto, B. Scammacca \& D. Serio. 1997. Contribution to the knowledge of benthic marine algae on rocky substrata of the Maltese Islands (Mediterranean Sea). Botanica Marina 40 (1-6): 203-205. DOI: 10.1515/botm.1997.40.1-6.203

Conde, F., A. Flores-Maya, J. Soto, M. Altamirano \& A. Sánchez. 1996. Checklist of Andalusia (S. Spain) seaweeds III. Rhodophyceae. Acta Botánica Malacitana 21: 7-33.

Conde, F. \& A. Flores-Maya. 2000. Nuevas adiciones al conocimiento de las macroalgas marinas de la isla de Alborán (Mediterráneo Occidental). Acta Botánica Malacitana 25: 180-184.

Coppejans, E. 1972. Resultats d'une étude systématique et écologique de la population algale des côtes rocheuses du Dramont, St Raphael (Var, France). Biologisch Jaarboek Dodonaea 40: 153-180.

Cowman, P.E \& D.R. BelLwood. 2013. Vicariance across major marine biogeographic barriers: temporal concordance and the relative intensity of hard versus soft barriers. Porceeding of The Royal Society B 280 (1768): 1-8. D0I: 10.1098\%2Frspb.2013.1541

Creed, M., M. T. Fuju, M. B. de B. Barreto, S.M.P. de B. Guimarães, V. Cassano, S. M. B. Pereira, M. de F. de 0. Carvalho \& S. Khader. 2010. In: Forzza, R.C. (Eds.). Catálogo de plantas e fungos do Brasil 1. Rhodophyceae. Pesquisas Jardim Botânico do Rio de Janeiro, pp. 426-436.

De Valéra, M., C. Pybus, B. Casley \& A. Webster. 1979. Littoral and benthic investigations on the west coast of Ireland $X$. Marine algae of the northern shores of the Burren, Co. Clare. Proceedings of the Royal Irish Academy 79B: 259-269. 
DIANNELIDIS, T. 1953. Contribution à la connaissance des algues marines des Sporades du Nord (Cyanophyceae, Chlorophyceae, Phaeophyceae, Rhodophyceae). Praktika Hellenic Hydrobiology Institute 6: 41-84.

Diapoulis, A., S. Haritonidis \& T. Koussouris. 1986. Spring benthic flora of Rhodos Island, Greece. Thalassographica 9: 49-57.

Díaz, P., I. Bárbara, A. Seclia, C. Peteiro, S. Calvo, N. Sánchez, A. Santolaria, I. Diez, T. Gallardo, J. Cremades \& J. M. Gorostiaga. 2008. Adiciones corológicas a la flora bentónica marina del Cantábrico. Nova Acta Científica Compostelana (Bioloxía) 17: 177-189.

Dimitrova-Konaklieva, S.D. 1981. Geographical analysis on the marine algae of the Black Sea in the Ahtopol area. Phytology 18: 22-35.

Dixon, P. S. 1961. List of marine algae collected in the Channel Islands during the joint meeting of the British Phycological Society and the Société Phycologique de France September 1960. British Phycological Bulletin 2 (2): 71-80. DOI: 10.1080/00071616100650061

Dizerbo, A. H. \& E. Herpe. 2007. Liste et répartition des algues marines des côtes françaises de la Manche et de l'Atlantique, îles Normandes incluses. Éditions Anaximandre, Landerneau. 315 p.

Duncan, E. J. \& L. M. LeE-Lum. 2006. A checklist of the marine macroalgae of the Republic of Trinidad and Tobago. Caribbean Marine Studies 7:1-96.

Edwards, P., E. Bird, B. Cotgreave, A. Cossins, K. Crompton, K. Fowler, D. HerdSON \& J. Hudson. 1975. Marine phytobenthos of the Castellabate (CiIento) Natural Park, Salerno, Italy. Phytocoenologia 1 (4): 403-246.

Feldmann, J. 1954. Inventaire de la flore marine de Roscoff. Algues, champignons, lichens et spermatophytes. Travaux Station Biologique de Roscoff. Nouvelle Série (Supplement 6): 152 p.

Feol, E. \& G. Bressan. 1972. Affinità florística dei tipi di vegetazione bentonica della Cala di Mitigliano (Massa Lubrense, Napoli). Giornale Botanico Italiano 106 (5): 245-256. DOI: 10.1080/11263507209426553

Fernández, C. \& J. J. Alvarado. 2004. El arrecife coralino de Punta Coclas, costa Caribe de Costa Rica. Revista Biología Tropical 52 (Supplement 2): 121-129.

FuJl, M. T. \& A. Sentíes. 2005. Taxonomia do complexo Laurencia (Rhodomelaceae, Rhodophyta) do Brasil, com ênfase nas especies dos estados de Sao Paulo e do Espíritu Santo. In: Sentíes, A. \& K.M. Dreckmann (Eds.). Monografías Ficológicas 2. UAM-Iztapalapa and Red Latinoamericana de Botánica, Cd. de Mexico. pp. 69-135,

Fujil, M. T., S. M. P. B. Guimaraes, C. F. D. Gurgel \& S. FredericQ. 2006. Characterization and phylogenetic affinities of the red algae Chondrophycus flagelliferus (Rhodomelaceae, Ceramiales) from Brazil on the basis of morphological and molecular evidence. Phycologia 45 (4): 432-441. DOI: 10.2216/04-33.1

Fujil, M. T., V. Cassano, E. M. Stein \& L. R. Carvalho. 2011. Overview of the taxonomy and of the major secondary metabolites and their biological activities related to human health of the Laurencia complex (Ceramiales, Rhodophyta) from Brazil. Brazilian Journal of Pharmacognosy 21 (2): 268-282. D0I: 10.1590/S0102-695X2011005000064
Furnari, G., M. Comarci \& D. Serio. 1999. Catalogue of the benthic marine macroalgae of the Italian coast of the Adriatic Sea. Bocconea 12: 5-214.

Furnari, G., M. Cormaci \& D. Serio. 2001. The Laurencia complex (Rhodophyta, Rhodomelaceae) in the Mediterranean Sea: an overview. Cryptogamie, Algologie 22 (4): 331-373.

Furnari, G., G. Glaccone, M. Comarci, G. Alongi \& D. Serio. 2003. Biodiversità marina delle coste italiane: catálogo de macrofitobenthos. Biologia Marina Mediterranea 10(1): 1-482.

GANESAN, E. K. 1990. A catalog of benthic marine algae and seagrasses of Venezuela. Fondo Editorial Conicit, Caracas. 237 p.

Garbary, D. J. \& J. T. HARPER. 1998. A phylogenetic analysis of the Laurencia complex (Rhodomelaceae) of the red algae. Cryptogamie, Algologie 19(3): 185-200.

Gil-Rodríguez, M. C., V. Cassano, E. Aylagas, A. Senties, J. Díaz-Larrea, M.C. OlivelRA \& M. T. FuJII. 2010. Palisada flagellifera (Ceramiales, Rhodophyta) from the Canary Islands, Spain: a new record for the eastern Atlantic 0cean based on morphological and molecular evidence. Botanica Marina 53 (1): 31-40. DOI: 10.1515/BOT.2010.010

Gil-Rodriguez M. C., M. T. Fujil, V. Cassano, M. Machín-Sánchez, E. Aylagas \& A. Sentíes. 2012. Los géneros Laurencia, Laurenciella y Palisada (Rhodomelaceae, Rhodophyta) en las Islas Canarias. In: A Sentíes \& K.M. Dreckmann (Eds.). Monografías Ficológicas 4. M: UAM-Iztapalapa and Universidad de La Laguna, Cd. de México. pp. 43-116

Gómez-Garreta, A., T. Gallardo, M. A. Ribera, M. Cormaci, G. Furnari, G. Giaccone \& C. F. Boudouresque. 2001. Checklist of the Mediterranean seaweeds III. Rhodophyceae Rabenh. 1. Ceramiales Oltm. Botanica Marina 44 (5): 425-460. DOI: 10.1515/B0T.2001.051

Gorostiaga, J. M., A. Santolaria, A. Secilia, C. Casares \& I. Diez. 2004. Checklist of the Basque coast benthic algae (North of Spain). Anales Jardín Botánico de Madrid 61 (2): 155-180.

Guiry, M. D. 1978. A consensus and bibliography of Irish Seaweeds. Cramer, Vaduz. $287 \mathrm{p}$.

GuIRY, M. D. \& G. M. Guiry. 2017. AlgaeBase. World-wide electronic publication. National University of Ireland, Ireland. Avaible online at: http://www.algaebase.org (downloaded March 25, 2017).

Hamel, C. 1928. Les algues de Vigo. Revue Algologique 4: 81-95.

HARDY, F. G. \& M. D. GuIRY. 2003. A check-list and atlas of the seaweeds of Britain and Ireland. British Phycological Society, London. $435 \mathrm{p}$.

Haroun, R. \& W. F. Prud'homme van Reine. 1993. A biogeographical study of "Laurencia" and "Hypnea" species of the Macaronesian region. Courier Forshungsinstitut Senckenberg 159: 119-125.

Haroun, R.J., M.C. Gill-Rodriguez, J. Díaz de Castro \& W.F. Prud'homme van REINE. 2002. A checklist of the marine plants from the Canary Islands (central eastern Atlantic 0cean). Botanica Marina 45 (2): 139-69.

Hoffman, R., M. Sternberg \& D. Serio. 2014. First report of Laurencia chondrioides (Ceramiales, Rhodophyta) and its potential to be an invasive in the eastern Mediterranean Sea. Botanica Marina 57 (6): 449-457. DOI: 10.1515/bot-2014-0053 
IPPI, S. \& V. FLORES, 2001. Las tortugas neotropicales y sus áreas de endemismo. Acta Zooogica Mexicana 84: 49-63.

John, D. M., W. F. Prudrhomme van Reine, G. W. Lawson, T. B. Kostermans \& J. H. PrICE. 2004. A taxonomic and geographical catalogue of the seaweeds of the western coast of Africa and adjacent islands. Beihefte zur Nova Hedwigia 127: 1-339.

Kamenarska, Z., A. Ivanova, R. Stancheva, M. Stoyneva, K. Stefanov, S. DimitroVA-KonAKLIEVA \& S. Popov. 2006. Volatile compounds from some Black Sea red algae and their chemotaxonomic application. Botanica Marina 49 (1): 47-56. DOI: 10.1515/BOT.2006.006

Kamenarska, Z., J. Serkedjeva, H. Najdenski, K, Stefanov, I. Tsvetkova, S. Dimitrova-Konakleva \& S. Popov. 2009. Antibacterial, antiviral, and cytotoxic activities of some red and brown seaweeds from Black Sea. Botanica Marina 52 (1): 80-86. D0I: 10.1515/B0T.2009.030

Kerswell, A. P. 2006. Global biodiversity patterns of benthic marine algae. Ecology 87 (10): 2479-2488. DOI: 10.1890/0012-9658(2006)87[2479:GBPOBM]2.0.C0;2

Klein, J. \& M. Verlaque. 2005. Laurencia caduciramulosa Masuda et Kawaguichi (Ceramiales, Rhodophyta), first record for the Mediterranean coast of France. Cryptogamie Algologie 26: 209-216.

Klein, J. C. \& M. Verlaque. 2011. Macroalgae newly recorded, rare or introduced to the French Mediterranean coast. Cryptogamie Algologie 31 (2): 111-130. D0I: 10.7872/crya.v32.iss2.2011.111

LIPKIN, Y. \& P. C. SILVA. 2002. Marine algae and seagrasses of the Dahlak Archipielago, southern Red Sea. Nova Hedwigia 75 (1-2): 1-90. D0I: 10.1127/0029-5035/2002/0075-0001.

LitTler, D. S. \& M. M. LitTler. 1997. An illustrated flora of Pelican Cays, Belize. Bulletin of the Biological Society of Washington 9: 1-149.

LitTler, D. S., M. M. LitTler \& M. D. Hanisak. 2008. Submersed plants of the Indian River Lagoon. OffShore Graphics, Washington, D.C. 286 p.

Machín-Sánchez, M., V. Cassano, J. Díaz-Larrea, A. Senties, M.T. Fujil \& M.C. GIL-RodRiguez. 2012. Morphological and molecular evidence demonstrate the amphi-Atlantic distribution of Laurencia catarinensis (Ceramiales, Rhodophyta). Botanica Marina 55 (3): 241-252. D0I: 10.1515/bot-2011-0049

Machín-Sánchez, M., L. Le Gall, A.I. Neto, F. Rousseau, V. Cassano, A. Senties, M.T. Fujli, J. Díaz-Larrea, W.F. Prud'homme van Reine, C. Bonillo \& M.C. GIL-RodRíGuez. 2014. A combined barcode and morphological approach to the systematics and biogeography of Laurencia pyramidalis and Laurencia marilzae (Rhodophyta). European Journal of Phycology 49 (1): 115-127. DOI: 10.1080/09670262.2014.893017

Martin-Lescanne, J., F. Rousseau, B. De Reviers, C. Payri, A. Couloux, C. Cruaud \& L. Le Gall. 2010. Phylogenetic analyses of the Laurencia complex (Rhodomelaceae, Ceramiales) support recognition of five genera: Chondrophycus, Laurencia, Osmundea, Palisada and Yuzurua stat. nov. European Journal of Phycology 45 (1): 51-61. D0l: $10.1080 / 09670260903314292$

Martínez-Gil, M., T. Gallardo, P. Díaz \& I. Bárbara. 2007. Aportación al conocimiento de las algas marinas bentónicas del litoral comprendido entre el estuario del Rio Quejo y Punta de la Mesa, Noja, Cantabria, España. Botánica Complutense 31: 41-53.
Mateo-Cid, L.E., A. C. Méndoza-González, A. Sentíes, J. Díaz-Larrea \& J. A. A. Calderon. 2014. Laurencia laurauertana sp. nov. (Rhodomelaceae, Rhodophyta): an epiphytic species from the Mexican Caribbean. Phycological Research 62 (2): 94-101. DOl: 10.1111/pre.12043

MEDINA. 2007. Empleo de herramientas panbiogeográficas para detectar áreas para conservar: Un ejemplo con taxones dulceacuícolas. In: Luna, I., J. J. Morrone \& D. Espinosa (Eds.). Biodiversidad de la Faja Volcánica Transmexicana. UNAM, Ciudad de México. Pp. 449-460.

Mettı Y., A. J. Millar \& P. Steinberg. 2015. A new molecular phylogeny of the Laurencia complex (Rhoodophyta, Rhodomelaceae) and a review of key morphological characters result in a new genus, Coronaphycus, and a description of C. novus. Journal of Phycology 51 (5): 929-942. DOI: 10.1111/jpy.12333

Miranda, T. P. \& A. C. Marques. 2011. Abordagens atuais em biogeografía marinha. Current approaches in marine biogeography. Revista da Biología (Vol. Esp. Biogeografía): p. 41-48. D0l: 10.7594/ revbio.07.08

Morrone, J. J. 2007. Evolutionary Biogeography: An Integrative Approach. Columbia University Press, New York. 301p.

Morrone, J. J. 2013. Parsimony analysis of endemicity (PAE) revisited. Journal of Biogeography 41 (5): 842-854. D0I: 0.1111/jbi.12251

Morton, 0. 1994. Marine algae of Northern Ireland. Ulster Museum, Botanic Gardens, Belfast. 123 p.

MoRTon, 0. 2003. The marine macroalgae of Country Donegal, Ireland. Bulletin of the Irish Biogeographical Society 27: 3-165.

Munda, I. M. 1979. Some Fucacean associations from the vicinity of Rovinj, Istrian Coast, northern Adriatic. Nova Hedwigia 31: 607-666.

Nam, K. W. 1999. Morphology of Chondrophycus undulatus and C. parvipapillata and its implications for the taxonomy of the Laurencia (Ceramiales, Rhodophyta) complex. European Journal of Phycology 34: 455-468.

NAm, K. W. 2006. Phylogenetic re-evaluation of the Laurencia complex (Rhodophyta) with a description of L. succulenta sp. nov from Korea. Journal of Applied Phycology 18: 679-697. D0l: 10.1007/ s10811-006-9073-3

Nam, K. W. 2007. Validation of the generic name Palisada (Rhodomelaceae, Rhodophyta). Algae 22 (2): 53-55.

Nam, K. W., C. A. Maggs \& D. J. Garbary. 1994. Resurrection of the genus Osmundea with an emendation of the generic delineation of Laurencia (Ceramiales, Rhodophyta). Phycologia 33 (5): 384-395. D0l: 10.2216/i0031-8884-33-5-384.1

Neto, A. I. 1994. Checklist of the benthic marine macroalgae of the Azores Archipélago. Life and Marine Sciences 12A: 15-34.

Neto, A. I., D. C. Cravo \& R. J. Haroun. 2001. Checklist of the benthic marine plants of the Madeira Archipiélago. Botánica Marina 44 (4): 391-414. DOI: 10.1515/BOT.2001.049

Nixon, K. C. 1999. Winclada (beta) ver 0.9.9. Published for the author, Ithaca, New York. 
Norris, J. N. \& K. E. BUCher. 1982. Marine algae and seagrasses from Carrie Bow Cay, Belize. In: Rützler K. \& I. G. Macintyre (Eds.). The Atlantic Barrier Reef Ecosystem at Carrie Bow Cay, Belize. I. Structure and Communities. Smithsonian Contributions to the Marine Sciences 12. pp. 167-223.

Núñez-Resendiz, M. L., K. M. Dreckmann, A. Sentíes, J. Diaz-Larrea \& G. C. ZucCARELLO. 2015. Genetically recognizable but not morphologically: the cryptic nature of Hydropuntia cornea and H. usneoides (Gracilariales, Rhodophyta) in the Yucatan Peninsula. Phycologia 54 (4): 407-416. DOI: 10.2216/15-009.1

Oliveira, A. S., D. B. Sudatti, M. T. Fujli, S. V. Rodríguez \& R. C. Pereira. 2013. Inter-and intrapopulation variation in the defensive chemistry of the red seaweed Laurencia dendroidea (Ceramiales, Rhodophyta). Phycologia 52 (2): 130-136. D0I: 10.2216/12-058.1

Ortega, M. M., J. L. Godínez \& G. Garduño Solórzano. 2001. Catálogo de algas bentónicas de las costas mexicanas del Golfo de México y Mar Caribe. Cuadernos del Instituto de Biología 34: 1-594.

Peña, V. \& I. Bárbara. 2008. Maërl community in the northwestern lberian Peninsula: a review of floristic studies and long-term changes. Aquatic Conservation: Marine and Freshwater Ecosystem 18: 339366.

Pérez-Ruzafa, I. \& M. Honrubia. 1984. Aportación al conocimiento de la flora algal bentónica de la costa murciana. III. Anales de Biología 2 (Sección Especial 2): 135-146.

Pérez-Ruzafa, I. M. 1990. Fenología de las algas del Mar Menor (Murcia, SE de España). Botanica Complutensis 16: 21-36.

Platnick, N. I. 1991. On areas of endemism. Australian Systematic Botany 4: 6-7.

Rindi, F., G. SaRTon \& F. Cinelul. 2002. A floristic account of the benthic marine algae of Tuscany (Western Mediterranean Sea). Nova Hedwigia 74(1-2): 201-250. DOI: 10.1127/0029-5035/2002/00740201

Rodriguez-Prieto, C., G. Michanek \& C. Ivon. 1999. Benthic marine algae from Martinique (Lesser Antilles). Scientia Gerudensis 24: 79-86.

Rodríguez-Prieto, C. \& L. Polo-Albertí. 1988. Aportación a la fenología de algas bentónicas de substrato duro de la Costa Brava (Gerona). Actes del Simposi Internacional de Botànica Pius Font I Quer 1, Criptogamia: 143-149.

Rodríguez-Prieto, C. \& L. Polo-Albertí. 1998. Anàlisi fitosociològica de la comunitat de Cystoseira mediterranea de Palamós (Mediterrània nordoccidental). Acta Botanica Barcinonensia 45: 141-156.

Rosen, B. R. 1988. From fossil to earth history: Applied historical biogeography. In: Myers A.A. \& P. Giller (Eds.). Analytical biogeography: an integrated approach to the study of animal and plant distributions. Wiley, Chichester, Sussex. pp. 201-262.

Rousseau, F., D. Gey, A. Kurihara, C.A. Maggs, J. Martin-Lescanne, C. Payri, B. de Reviers, A.R. Sherwood \& L. Le Gall. 2017. Molecular phylogenies support taxonomic revision of three species of Laurencia (Rhodomelaceae, Rhodophyta), with the description of new genus. European Journal of Taxonomy 269: 1-19. D0I: 10.5852/ejt.2017.269
SAito, Y. 1967. Studies on Japanese species of Laurencia with special reference to their comparative morphology. Memoirs of the Faculty of Fisheries, Hokkaido University 15: 1-81.

SALES, M. \& E. BALLESTEROS. 2010. Long-term comparison of algal assemblages dominated by Cystoseira crinite (Fucales, Heterokontophyta) from Cap Corse (Corsica, north western Mediterranean. European Journal of Phycology 45 (4): 404-412. DOl: 10.1080/09670262.2010.498585

SChneider, C.W. \& C.E. LANe. 2005. Notes on the marine algae of the Bermudas.7. Additions to the flora, including Chondracanthus saundersii sp. nov. (Rhodophyta, Gigartinales) based on $r b c \mathrm{~L}$ sequence analysis. Phycologia 44: 72-83.

Schneider, C. W., C. E. Lane \& G. W. Saunders. 2010. Notes on the marine algae of the Bermudas. 11. More additions to the benthic flora and a phylogenetic assessment of Halymenia pseudofloresii (Halymeniales, Rhodophyta) from its type locality. Phycologia 49 (2): 154168. DOI: 10.2216/PH09-46.1

SCHNetter, R. 1976. Nuevas algas benticas del litoral Caribe de Colombia. Caldasia 11 (53): 57-60.

Sentís, A. \& M. T. FuJII. 2002. El complejo Laurencia (Rhodomelaceae, Rhodophyta) en el Caribe Mexicano. In: Sentíes, A. \& K.M. Dreckmann (Eds.). Monografías Ficológicas 1. UAM-Iztapalapa and Red Latinoamericana de Botánica, Cd. de Mexico. pp. 119-192.

Senties, A., A. Areces, J. Díz-Larrea \& M.T. FuJll. 2010. First records of Laurencia caduciramulosa and $L$. minuscula (Ceramiales, Rhodophyta) from the Cuban archipelago. Botanica Marina 53 (5): 433-438. DOI: 10.1515/bot.2010.048

Serio, D., G. Furnari \& M. Comarci. 2004. On the occurrence of Laurencia pyramidalis Bory ex Kutzing (Rhodophyta, Ceramiales) in the Mediterranean Sea. Cryptogamie Algologie 25 (4): 329-336.

Serio, D., G. Alongl, M. Catra, M. Comarci \& G. Furnari. 2006. Changes in the benthic algal flora of Linosa Island (Straits of Sicily, Mediterranean Sea). Botanica Marina 49 (2): 135-144. D0I: 10.1515/BOT.2006.018

Silva, P. C., E. G. Meñez \& R. L. MoE. 1987. Catalog of the benthic marine algae of the Philippines. Smithsonian Contributions to Marine Sciences 27: 1-179. D0I: 10.5479/si.1943667X.27.1

Silva, P. C. P. W. Basson \& R. L. MoE. 1996. Catalogue of the benthic marine algae of the Indian Ocean. University of California Publications in Botany 79: 1-1259.

Skage, M., T.M. Gabrielsen \& J. Rueness. 2005. A molecular approach to investigate the phylogenetic basis of three widely used species groups in the red algae genus Ceramium (Ceramiales, Rhodophyta). Phycologia 44: 353-360.

Soto, J. \& F. Conde. 1989. Catálogo florístico de las algas bentónicas marinas del litoral de Almería (Sureste de España). Botánica Complutense 15: 61-83.

Spalding, M. K., H. E. Fox, G. R. Allen, N. Davidson, Z. A. Ferdaña, M. Finlayson, B. J. Halpern, M. A. Jorge, A. Lombarda, S. A. Lourie, K. D. Martin, E. McManus, J. Molnar, C. A. Ricchia \& J. Robertson. 2007. Marine ecoregions of the world: a bioregionalization of coastal and shelf areas. BioScience 57 (7): 573-583. D0I: 10.1641/B570707

Stegenga, H., J. J. Bolton \& R. J. Anderson. 1997. Seaweeds of the South African west coast. Bolus Herbarium, University of Cape Town. 655 p. 
Stokes, K., K. O'NeILl \& R.A. McDonald. 2004. Invasive species in Ireland. Unpublished report to Environment \& Heritage Service and Natural Parks \& Wildlife Service, Belfast. 152 p.

SuÁrez, A. M. 2005. Lista de las macroalgas marinas cubanas. Revista de Investigaciones Marinas 26 (2): 93-148.

Sú́rez, A. M., B. Martínez-Daranas \& Y. Alfonso 2015. Macroalgas marinas de Cuba. Editorial UH, La Habana. 264 p.

Tapia-Silva, F. 0., 0. E. Hernández-Cervantes, M. I. Vilchis-Alfaro, A. Sentíes \& K. M. DreCKMAnn. 2015. Mapping of algae richness using spatial data interpolation. The International Archives of the Photogrammetry, Remote Sensing ans Spatial Information Sciences XL-7/W3: 1005-1008. DOI: 10.5194/isprsarchives-XL-7-W3-1005-2015

TASKIN, E., M. ÖZTÜRK, 0. KuRT \& M. ÖzTURK. 2008. The check-list of the marine algae of Turkey. Ecem Kirtasiye, Manisa. 87 p.

TASKIN, E., M. ÖZtürk, O. KuRt \& S. Uclay. 2013. Benthic marine algae in the Northern Cyprus (eastern Mediterranean Sea). Journal of Black Sea/Mediterranean Enviroment 19 (2): 143-161.

TAYLOR, W. R. 1960. Marine algae of the eastern tropical and subtropical coasts of the Americas. The University of Michigan Press, Ann Arbor. $870 p$

TAYLOR, W. R. 1969. Notes on the distribution of West Indian marine algae particularly in the Lesser Antilles. Contribution from the University of Michigan Herbarium 9: 125-203.

Tittensor, D. P., C. Mora, W. Jetz, H. K. Lootze, D. Ricard, E. V. Berghe \& B. WoRM. 2010. Global patterns and predictors of marine biodiversity across taxa. Nature Letters 466 (7310): 1098-1103. D0I: 10.1038/ nature09329

Tittley I. \& A. I. Neto. 1994. "Expedition Azores 1989": Benthic marine algae (seaweeds) recorded from Faial and Pico. Archipélago. Life and Marine Sciences 12A: 1-13.

Tittley, I., A. I. Neto \& M. I. Parente. 2009. The marine algal (seaweed) flora the Azores: additions and amendments 3. Botanica Marina 52 (3): 7-14. DOI: 10.1515/BOT.2005.030

Torrano-Silva, B. N. \& OliveiRA, E. C. 2013. Macrophytobenthic flora of the Abrolhos Archipelago and the Sebastião Gomes Reef, Brazil. Continental Shelf Research 70: 150-158. D0I: 10.1016/j.csr.2013.09.019

Tsiamis, K., A. F. Peters, D. N. Shewring, A. 0. Asensi, P. Van West \& F. C. KüpPER. 2014a. Marine benthic algal flora of Ascension Island, South Atlantic. Journal of Marine Biological Association of the United Kingdom [advance access]: 1-8. DOI: 10.1017/S0025315414000952
Tsiamis, K., E. Taskin, S. Orfanidis, P. Stavrou, M. Argyrou, P. Panayotidis, T. TSIOLI, B. A. Cicek, M. Marcou \& F. C. Küpper. 2014b. Checklist of seaweeds of Cyprus (Mediterranean Sea). Botanica Marina 57 (3): 153166. DOI: $10.1515 /$ bot-2014-0006

TSIIIRA, A. \& S. HARITONIDIS. 2005. A survey of the benthic flora in the National Marine Park of Zakynthos (Greece). Botanica Marina 48 (1): 38-45. DOI: 10.1515/BOT.2005.002

TuYA, F. \& R. J. HARoun. 2009. Phytogeography of Luisitanian Macaronesia: biogeographic affinities in species richness and assemblage composition. European Journal of Phycology 44 (3): 405-413. D0l: $10.1080 / 09670260902836246$

Vargas, S., H.M. Guzman \& 0. Breedy. 2008. Distribution patterns of the genus Pacifigorgia (Octocorallia: Gorgoniidae): track compatibility analysis and parsimony analysis of endemicity. Journal of Biogeography 35 (2): 241-247.

Veiga, A. J., J. Cremades \& I. Bárbara. 1998. A catalogue of the benthic marine algae of the Sisargas Islands (N.W. Iberian Peninsula, Spain). Boletim do Museu Municipal do Funchal (Suppl. 5): 481-493.

VerLAQUE, M. 2001. Checklist of the macroalgae of Thau Lagoon (Hérault, France), a hot spot of marine species introduction in Europe. Oceanologica Acta 24 (1): 29-49. DOI: 10.1016/S0399-1784(00)01127-0

Vilchis, M.I., K.M. Dreckmann, E.A. García-Trejo, 0.E. Hernández \& A. Sentíes. (in press). Patrones de distribución de las grandes macroalgas en el Golfo de México y Caribe mexicano: Una contribución a la biología de la conservación. Revista Mexicana de Biodiversidad.

Villaça, R., A. C. Fonseca, V. K. Jensen \& B. Knoppers. 2010. Species composition and distribution of macroalgae on Atol das Rocas, Brazil, SW Atlantic. Botanica Marina 53 (2): 113-122. DOI: 10.1515/ BOT.2010.013

WOMERSLEY, H. B. S. 2003. The marine benthic flora of southern Australia - Part IIID Ceramiales - Delesseriaceae, Sarcomeniaceae, Rhodomelaceae. Australian Biological Resources Study/State Herbarium of South Australia, Canberra/Adelaide. 533 p.

Wynne, M. J. 2008. A checklist of the benthic marine algae of the coast of Texas. Gulf of Mexico Science 2008 (1): 64-87.

WYNNE, M. J. 2017. A checklist of benthic marine algae of the tropical and subtropical western Atlantic: fourth revisión. Nova Hedwigia Beihefte 145: 7-202.

Wynne, M. J., T. Bradshaw \& C. M. S. Carrington. 2014. A checklist of the benthic marine algae of Barbados, West Indies. Botanica Marina 57 (3): 167-184. DOl: 10.1515/bot-2014-0007 